\title{
Evaluation of intravenous iron sucrose therapy for management of moderate to severe anaemia in pregnancy
}

\author{
Pankajkumar B. Nimbalkar ${ }^{1}$, Jaldhara N. Patel ${ }^{2 *}$, Nilesh Thakor ${ }^{3}$
}

\begin{abstract}
${ }^{1}$ Department of Obstetrics and Gynecology, GMERS Medical College, Dharpur-Patan, Gujarat, India ${ }^{2}$ Department of Obstetrics and Gynecology, ${ }^{3}$ Department of Community Medicine, GMERS Medical College, Gandhinagar, Gujarat, India
\end{abstract}

Received: 25 October 2017

Accepted: 11 November 2017

\section{*Correspondence:}

Dr. Jaldhara N. Patel,

E-mail: researchforbetterhealth@gmail.com

Copyright: (c) the author(s), publisher and licensee Medip Academy. This is an open-access article distributed under the terms of the Creative Commons Attribution Non-Commercial License, which permits unrestricted non-commercial use, distribution, and reproduction in any medium, provided the original work is properly cited.

\begin{abstract}
Background: Iron deficiency anaemia (IDA) is the most common nutritional deficiency in pregnancy and major contributory factor to maternal morbidity and mortality. Objective of present study was to evaluate the response and effectof parenteral iron sucrose complex therapy in iron deficiency anemia in pregnancy.

Methods: A prospective observational study was conducted at GMERS Medical College, Dharpur-Patan over a period extending from September 2014 to August 2017. A total of 150 Antenatal women, between 26-32 weeks of pregnancy with hemoglobin between 5-9 gm\% were selected for study by purposive sampling. They were given intravenous iron sucrose complex in a dose of $200 \mathrm{mg}$ ( 2 ampules of $5 \mathrm{ml}$ each) in $100 \mathrm{ml}$ normal saline over a period of 15-20 minutes, on alternate day. Repeat CBC was done after a period of 6 weeks.

Results: Age range of the patients was 20 to 34 years. Out of total 150 women, 72 women (48\%) were in age group of 20-24 years. $64.6 \%$ women had 27-29 weeks of pregnancy. $58(38.6 \%)$ women had $<8$ gm\% of $\mathrm{Hb}$ before treatment and $108(72 \%)$ women achieved $\mathrm{Hb}$ of $10 \mathrm{gm} \%$ after treatment. The mean haemoglobin raised from $7.9 \pm 0.92 \mathrm{gm} \%$ to $10.3 \pm 0.83 \mathrm{gm} \%(\mathrm{P}<0.001)$ after six weeks of therapy. There was significant rise in MCV levels (from $67.7 \pm 5.1 \mathrm{fl}$ to $78.9 \pm 6.4 \mathrm{fl})(\mathrm{P}<0.001)$. Major side effects or anaphylactic reactions were occurred in none of the women during study period. $93.3 \%$ of patients, treated for anemia were delivered at full term, either vaginally $(67.3 \%)$ or by LSCS (26\%). Most of the delivered babies (80\%), had birth weight of more than $2.5 \mathrm{kgs}$.

Conclusions: Parentral iron therapy was effective in increasing haemoglobin and other haematological parameters in pregnant women with moderate to severe anaemia.
\end{abstract}

Keywords: Anaemia, Iron deficiency, Iron sucrose complex, MCV, Parentral iron therapy

\section{INTRODUCTION}

Iron deficiency anaemia (IDA) is the most common nutritional deficiency in pregnancy. According to WHO anaemia is defined as "haemoglobin less than $11 \mathrm{gm} / \mathrm{dl}$ and a haematocrit of less than 0.33 . Most women begin their pregnancy with partially or completely depleted iron reserves. Thus, the severity of the anaemia is inversely related to the amount of iron reserves. ${ }^{1,2}$
In underdeveloped countries, anaemia is a major contributory factor to maternal morbidity and mortality. WHO has estimated prevalence of anemia in developed and developing countries in pregnant women are 14 percent in developed and 51 percent in developing countries and 65-75 percent in India. ${ }^{3}$ Prevalence of anemia in all groups is higher in India as compared to other developing countries. As per National Family Health Survey- 4 (NFHS-4) prevalence of Iron deficiency 
anaemia (IDA) in pregnant women is $50.3 \%$ in India and $51.3 \%$ in Gujarat. ${ }^{4,5}$

Various modalities of management of IDA like oral, intramuscular and intravenous preparations of iron have been used in the pregnant patientsbut efficacy of oral iron therapy may be limited in many patients because of dose dependent side-effects, non-compliance, and poor absorption and not possible to achieve the target rise in $\mathrm{Hb}$ level in a limited time-period when patient is approaching the term. Iron sucrose complex (ISC) is a relatively new drug, which is used intravenously for the correction of IDA. ${ }^{3}$ The drug has been able to raise the $\mathrm{Hb}$ to satisfactory level when used in severely anemic iron deficient pregnant women. 6,7

Recent evidence suggests that iron sucrose can be detected in high levels in liver circulation and marrow within 5 min after intravenous administration. ${ }^{8}$ Also, the accumulation of iron sucrose in organic parenchyma is much lower compared with iron-dextrans and irongluconate. ${ }^{9}$

Thus, Iron sucrose has revolutionized anemia management in pregnancy. This study was under taken to evaluate the response and effect of parenteral iron sucrose complex therapy in iron deficiency anemia in pregnancy.

\section{METHODS}

A prospective observational study was conducted at the department of Obstetrics and Gynaecology, GMERS Medical College, Dharpur-Patan over a period extending from September 2014 to August 2017. A total of 150 Antenatal women, between 26-32 weeks of pregnancy with hemoglobin between 5-9 gm.\% were selected for study by purposive sampling. After admission in hospital wards, written informed consent was taken prior to screening enrolment. The procedure, possible complications and chances of failure of the procedure were explained to each patient in detail. Before conducting the study, approval was obtained from institutional ethical committee for human research. Data safety and confidentiality was also given due consideration. The file containing identity related details was kept password protected and the filled Performa were kept in lock with key accessible only to researcher.

After excluding other causes of anaemia e.g. Thalassemia, Haemolytic anaemia, hypersplenism, infection, inflammation, liver or renal disease subjects were administered Parenteral Iron Sucrose (ISC) therapy. All the patients received ISC in infusion form with the aim to correct the iron deficiency as well as to replenish the iron stores. The aim was to bring her $\mathrm{Hb}$ level to $10 \mathrm{gm} \%$. Formulae were used to calculate the iron requirement of the patient to fulfill the deficit as well as to replenish the iron stores and were calculated as follows: Amount of iron deficit $(\mathrm{mg})=$ Body wt $(\mathrm{Kg}) \times$ $\mathrm{Hb}$ deficit $(\mathrm{gm} \%) \times 0.24+500$
ISC was administered as $200 \mathrm{mg}$ elemental iron in $100 \mathrm{ml}$ $0.9 \%$ Normal Saline infusion over 1 hour on alternate days up to the total calculated dose. A test dose of one ml of Iron Sucrose infusion was given and followed by a 15 minutes window period, during which no infusion was given, and patient was observed for any allergic reactions. If no reactions occurred, the rest of the infusion was given. Repeat $\mathrm{CBC}$ was done after a period of 6 weeks.

Monitoring during infusion: A set of observations (BP, pulse, temperature) were taken before the start of the infusion, after 15 minutes and at the end of the infusion. Similar clinical observations were taken as and when required during blood transfusion i.e. looking for symptoms or signs of an adverse reaction. The subjects were allowed to go home four hours after the infusion if all observations were stable. Mild allergic reactions were managed by stopping the administration of ISC and giving Injection Chlorpheniramine $10 \mathrm{mg}$ IV slowly. The infusion was then being restarted at a slower rate and the women observed closely. Mean values of $\mathrm{Hb}$ and $\mathrm{MCV}$ were used to compare pre and post treatment parameters. $\mathrm{p}$ value of less than 0.5 was considered to be significant. ${ }^{3}$ The data was compiled and standard tests of significance (p-value) were applied.

\section{RESULTS}

Age range of the patients was 20 to 34 years. Out of total 150 women, 72 women $(48 \%)$ were in age group of 20 24 years followed by $40.6 \%$ women in the age group of 25-29 years (Table 1).

Table 1: Distribution of women according to their age.

\begin{tabular}{|ll|}
\hline Age (Years) & No. of patients, $(\%)$ \\
\hline $20-24$ & $72(48.0)$ \\
\hline $25-29$ & $61(40.6)$ \\
\hline $30-34$ & $17(11.4)$ \\
\hline Total & $150(100)$ \\
\hline
\end{tabular}

Out of total, $64.6 \%$ women had 27-29 weeks of pregnancy. Only $4.7 \%$ women had 32 weeks of pregnancy (Table 2).

Table 2: Distribution of women according to their gestational weeks (USG maturity).

\begin{tabular}{|ll|}
\hline USG Maturity in weeks & No. of Pts., $(\%)$ \\
\hline 26 & $9(6.0)$ \\
\hline 27 & $33(22.0)$ \\
\hline 28 & $29(19.3)$ \\
\hline 29 & $35(23.3)$ \\
\hline 30 & $17(11.3)$ \\
\hline 31 & $20(13.3)$ \\
\hline 32 & $07(4.7)$ \\
\hline Total & $150(100)$ \\
\hline
\end{tabular}


Out of total 150 women, $58(38.6 \%)$ women had $<8 \mathrm{gm} \%$ of $\mathrm{Hb}$ before treatment and $108(72 \%)$ women achieved $\mathrm{Hb}$ of $10 \mathrm{gm} \%$ after treatment (Table 3 ).

Table 3: Rise in hemoglobin level of pregnant women.

\begin{tabular}{|llll|}
$\begin{array}{l}\text { Pre treatment } \\
\text { hemoglobin }\end{array}$ & \multicolumn{3}{l}{$\begin{array}{l}\text { Post treatment } \\
\text { hemoglobin }\end{array}$} \\
\hline HB (gm\%) & $\begin{array}{l}\text { No. of } \\
\text { Pts., }(\%)\end{array}$ & HB (gm\%) & $\begin{array}{l}\text { No. of } \\
\text { Pts., }(\%)\end{array}$ \\
\hline $6.0-6.9$ & $17(11.3)$ & $9.0-9.9$ & $42(28.0)$ \\
\hline $7.0-7.9$ & $41(27.3)$ & $10.0-10.9$ & $95(63.3)$ \\
\hline $8.0-8.9$ & $92(61.3)$ & $11.0-11.9$ & $13(8.7)$ \\
\hline Total & 150 & Total & 150 \\
\hline
\end{tabular}

The mean haemoglobin raised from $7.9 \pm 0.92 \mathrm{gm} \%$ to $10.3 \pm 0.83 \mathrm{gm} \%(\mathrm{P}<0.001)$ after six weeks of therapy (Table 4).

Table 4: Mean rise in hemoglobin of pregnant women before and after treatment.

\begin{tabular}{lll}
$\begin{array}{l}\text { Mean } \\
\text { hemoglobin } \\
\text { pre-treatment }\end{array}$ & $\begin{array}{l}\text { Mean } \\
\text { hemoglobin } \\
\text { post-treatment }\end{array}$ & $\begin{array}{l}\text { Mean rise in } \\
\text { hemoglobin }\end{array}$ \\
\hline $7.9 \pm 0.92$ gm\% & $10.3 \pm 0.83$ gm\% & $2.4 \pm 0.9$ gm\% \\
\hline
\end{tabular}

There was significant rise in MCV levels (from 67.7 \pm 5.1 fl to $78.9 \pm 6.4 \mathrm{fl})(\mathrm{P}<0.001)$ (Table 5).

Table 5: Rise in mean corpuscular volume of pregnant women before and after treatment.

\begin{tabular}{|c|c|c|}
\hline $\begin{array}{l}\text { Pre-treatment } \\
\text { mean } \\
\text { corpuscular } \\
\text { volume } \\
\text { (femtoliters) }\end{array}$ & $\begin{array}{l}\text { Post-treatment } \\
\text { mean } \\
\text { corpuscular } \\
\text { volume } \\
\text { (femtoliters) }\end{array}$ & $\begin{array}{l}\text { Rise in } \\
\text { mean } \\
\text { corpuscular } \\
\text { volume } \\
\text { (femtoliters) }\end{array}$ \\
\hline $67.7 \pm 5.1 \mathrm{fl}$ & $78.9 \pm 6.4 \mathrm{fl}$ & $11.2 \pm 1.3 \mathrm{fl}$ \\
\hline
\end{tabular}

Major side effects or anaphylactic reactions were occurred in none of the women during study period. $93.3 \%$ of patients, treated for anemia were delivered at full term. Out of total, $26 \%$ women delivered at full term through Lowe Segment Cesarian Section (LSCS). Only $6.7 \%$ women had preterm deliveries (Table 6).

Table 6: Distribution of women according to their outcome of pregnancy.

\begin{tabular}{|ll|} 
Oult term deliveries & No. of patients \\
\hline $\begin{array}{l}\text { Full term deliveries through lower } \\
\text { segment cesarian section }\end{array}$ & $101(67.3)$ \\
\hline Preterm deliveries & $39(26.0)$ \\
\hline Total & $10(6.7)$ \\
\hline
\end{tabular}

Most of the delivered babies (80\%), had birth weight of more than $2.5 \mathrm{kgs}$. Out of total, $17(11.3 \%)$ women had delivered babies with $2.0-2.4 \mathrm{Kg}$ birth weight. Only $8.7 \%$ women had delivered babies with less than $2 \mathrm{Kg}$ birth weight (Table 7).

Table 7: Distribution of women according to birth weight of delivered child.

$\begin{array}{ll}\text { Birth weight of delivered child (kg.) } & \text { No. of women } \\ <2.05 & 13(8.7) \\ 2.0-2.4 & 17(11.3) \\ 2.5-2.9 & 85(56.7) \\ >3.0 & 35(23.3) \\ \text { Total } & 150(100)\end{array}$

\section{DISCUSSION}

Iron-deficiency anaemia is a major health problem worldwide, but responds well to iron supplementation. New approaches are leading to more effective management of this condition. The introduction of second-generation i.v. iron formulations, including iron sucrose and ferric gluconate, was clearly an improvement over i.v. iron dextran. These formulations proved to be effective in the management of IDA and are not associated with the serious allergic reactions encountered with i.v. iron dextrans.

An important advantage of i.v. iron over oral iron is that it may bypass hepcidin actions by directly loading transferrin and making iron available to macrophages. Iron deficiency is usually suspected in at-risk patients with declining haemoglobin $(\mathrm{Hb})$ levels and then confirmed by measuring serum ferritin levels and transferring saturation. Patients are commonly prescribed oral iron preparations because of convenience and low cost. However, the efficacy of these agents is limited by their reduced absorption rate and gastrointestinal sideeffects and compliance.

In present study out of total 150 women, 72 women (48\%) were in age group of 20-24 years. Out of total, $64.6 \%$ women had 27-29 weeks of pregnancy. Out of total 150 women, $58(38.6 \%)$ women had $<8 \mathrm{gm} \%$ of $\mathrm{Hb}$ before treatment and $108(72 \%)$ women achieved $\mathrm{Hb}$ of $10 \mathrm{gm} \%$ after treatment. The mean haemoglobin raised from $7.9 \pm 0.92 \mathrm{gm} \%$ to $10.3 \pm 0.83 \mathrm{gm} \%(\mathrm{P}<0.001)$ after six weeks of therapy. There was significant rise in MCV levels (from 67.7 $\pm 5.1 \mathrm{fl}$ to $78.9 \pm 6.4 \mathrm{fl})(\mathrm{P}<0.001)$.

Major side effects or anaphylactic reactions were occurred in none of the women during study period. $93.3 \%$ of patients, treated for anemia were delivered at full term, either vaginally $(67.3 \%)$ or by LSCS $(26 \%)$. Most of the delivered babies $(80 \%)$, had birth weight of more than $2.5 \mathrm{kgs}$.

In Thakor $\mathrm{N}$ et al out of total 75 women, Majority of the women $(48 \%)$ were in age group of 20-24 years. $^{3}$ Majority of the women $65.2 \%$ ) had 27-29 weeks of pregnancy. $40 \%$ women had $<8 \mathrm{gm} \%$ of $\mathrm{Hb}$ before treatment. $65.4 \%$ women achieved $\mathrm{Hb}$ of $10 \mathrm{gm} \%$. The 
mean haemoglobin raised from $7.8 \pm 0.61 \mathrm{gm} \%$ to $10.1 \pm 0.73(\mathrm{P}<0.001)$ after six weeks of therapy. There was significant rise in MCV levels (from 67.8 $\pm 5.0 \mathrm{fl}$ to $79.2 \pm 2.3 \mathrm{fl})(\mathrm{P}<0.001)$.

Major side effects or anaphylactic reactions were occurred in none of the women during study period. $91 \%$ of patients, treated for anemia were delivered at full term, either vaginally $(65.33 \%)$ or by LSCS $(25.3 \%)$. Most of the delivered babies (80\%), had birth weight of more than $2.5 \mathrm{kgs}$.

In Kriplani Alka et al the mean age of women was 27.8 \pm 3.9 (range 21-34) year and mean parity was 1.3; mean period of gestation (PDG) at the time of diagnosis was $25.69 \pm 4.82$ (14-32) weeks. At the beginning, mean $\mathrm{Hb}$ was $7.63 \pm 0.61 \mathrm{~g} \%$. Thirty two $(32 \%)$ women had mild anaemia (>8 g\%) and 68 per cent had moderate anaemia (5-7.9\%). After completion of therapy, mean $\mathrm{Hb}$ raised to $11.20 \pm 0.73 \mathrm{~g} \%$. Of the total women, 67 per cent achieved $\mathrm{Hb} \geq 11 \mathrm{~g} \%{ }^{10}$

In Patel $\mathrm{S}$ et al intravenous iron sucrose is effective in achieving target $\mathrm{Hb}$ of $10 \mathrm{~g} / \mathrm{dl}$ in $80 \%$ of patients. It shows that of IV iron sucrose significantly $(\mathrm{P}<0.001)$ increase Hb levels within 4 weeks. There were no major adverse reactions. ${ }^{11}$ Neeru $\mathrm{S}$ et al rise in mean $\mathrm{Hb}$ was 2.06 gm\%. ${ }^{12}$ In Al-Memon $\mathrm{AK}$ et al rise in mean $\mathrm{Hb}$ was 2.5 gm\% and rise in mean MCV was $10 \mathrm{ft} .{ }^{13}$ In Kiran KV et al rise in mean $\mathrm{Hb}$ was $2.53 \mathrm{gm} \% .{ }^{14}$ In Raja $\mathrm{K}$ et al rise in mean $\mathrm{Hb}$ was $3.5 \mathrm{gm} \%$ andrise in mean MCV was $10 \mathrm{ft}{ }^{15}$ Halimi S, et al. the mean haemoglobin raised from $9.2 \pm 1.69 \mathrm{gm} \%$ to $12.65 \pm 1.06$ after 30 days of therapy. ${ }^{16}$

However, study done in single college of Dharpur-Patan city limits us to generalize the results. There is definitely a need for well-planned, large-scale studies using standardized methodologies to evaluate patient satisfaction and quality of life, impact on costs and hospital stay, impact on blood transfusion frequency and mortality rate and finally to see impact on other factors such as breast feeding behavior and neonatal outcome such as birth weight, prematurity and neonatal iron stores.

\section{CONCLUSION}

Parentral iron therapy was effective in increasing haemoglobin and other haematological parameters in pregnant women with moderate to severe anaemia. If used in time, this treatment will certainly help to reduce the risk of maternal and foetal complications as well as it also reduce the risk of blood transfusion during peripartum period. It is safe and well tolerated. In our country with high prevalence of IDA during in pregnancy, this type of treatment may be helpful in management of these patients. Limitations with intravenous iron replacement include the need for medical supervision in the setting of limited healthcare resources; the need for patients to take multiple days off work and the cost of IV iron.
Funding: No funding sources

Conflict of interest: None declared

Ethical approval: The study was approved by the Institutional Ethics Committee

\section{REFERENCES}

1. Breymann C. Iron deficiency and anemia in pregnancy: modern aspects of diagnosis and therapy. Blood Cells Mol Dis. 2002;29:506-16.

2. Khan MM. Effects of maternal anemia on fetal parameters. J Ayub Med Coll Abbottabad. 2001;13:38-41.

3. Thakor N, Bhagora S, Asari U, Kharadi A, pandor J, prajapati D. Effect of intravenous iron sucrose therapy for moderate-to-severe anemia in pregnancy: a longitudinal study. Int J Med Sci Public Health. 2015;4:11-14.

4. International institute for population sciences (IIPS) and macro International. 2016. National family health survey (NFHS-4), India, 2015-16: India. Mumbai: IIPS. Available at http://rchiips.org/NFHS/pdf/NFHS4/India.pdf. Accessed on 15 October 2017

5. International institute for population sciences (IIPS) and macro International. 2016. National family health survey (NFHS-4), India, 2015-16: Gujarat. Mumbai: IIPS Available at http://rchiips.org/NFHS/pdf/NFHS4/GJ_FactSheet.p df Accessed on 15 October 2015

6. Saeed GA. A 52-year-old lady presenting with pregnancy and anemia. Pak Armed Forces Med J. 2002;52:223-4.

7. Ahmed K, Sadiq I, Yousuf AW. Injectable iron therapy: intramuscular Vs intravenous therapy. Biomedica. 2000;16:44-7.

8. Wali A, Mushtaq A, Nilofer. Comparative study: efficacy, safety and compliance of intravenous iron sucrose and intramuscular iron sorbitol in iron deficiency anemia of pregnancy. J Pak Med Assoc. 2002;52:392-5.

9. Giannoulis C, Daniilidis A, Tantanasis T, Dinas K, Tzafettas J. Intravenous administation of iron sucrose for treating anemia in postpartum women. Hippokratia. 2009;13:38-40.

10. Kriplani A, Mahey R. Intravenous iron sucrose therapy for moderate to severe anaemia in pregnancy, Indian J Med Res. 2013;138(1):78-82.

11. Patel S, Goyal A, Shrivastava A, Verma R. Safety and efficacy of parenteral iron sucrose complex therapy in iron deficiency anemia in antenatal and postnatal women. Int $\mathrm{J}$ Med Sci Public Health. 2013;2:360-3.

12. Neeru S, Nair NS, Rai L. Iron sucrose versus oral iron therapy in pregnancy anemia. Indian $\mathbf{J}$ Community Med. 2012;37:214-8.

13. Al-Memon AK, al-Meshari A, al-Nuaim L, Saddique A, Abotalib Z, Khashogji $\mathrm{T}$ et al. Intravenous iron sucrose complex in the treatment of iron deficiency 
anemia during pregnancy. Eur J Obstet Gynec. 1996 Nov, 69(2);121-4.

14. KV K, Guru PB, Srinivasa RK, Manavalan R, Manna PK, Mohanta GP et al. Study of effect of intravenous iron sucrose in the treatment of puerperal anemia. Indian J Pharm Pract. 2010 Oct;3(4):14.

15. Raja K, Janjua NB, Khokhar N. Intravenous iron sucrose therapy in iron deficiency anemia in pregnancy. J Pak Med Assoc. 2003;28(2).

16. Halimi S, Halimi SM, Shoaib M. Oral versus parenteral iron therapy for correction of iron deficiency anaemia in pregnancy. Gomal J Med Sci. 2010 Dec 31;9(1):3-5.

Cite this article as: Nimbalkar PB, Patel JN, Thakor N. Evaluation of intravenous iron sucrose therapy for management of moderate to severe anaemia in pregnancy. Int J Reprod Contracept Obstet Gynecol 2017;6:5272-6. 